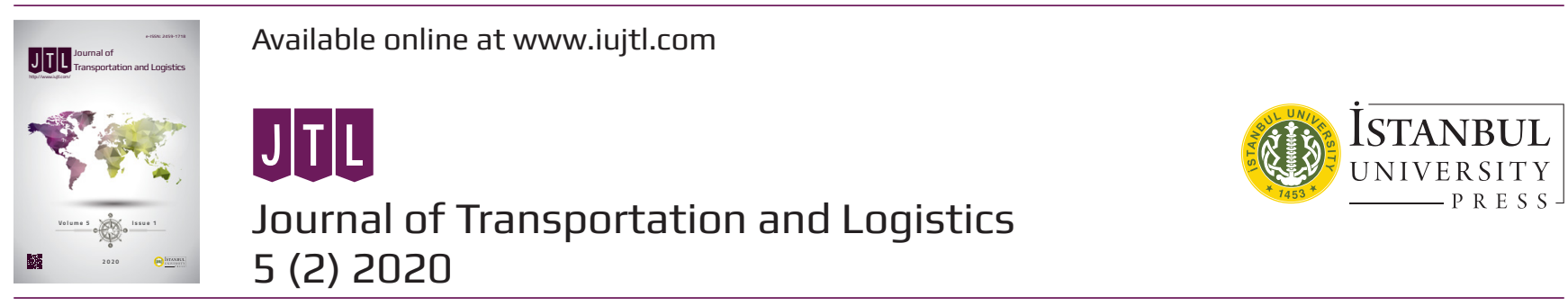

\title{
Settlement of Railway Track on Reinforced Ballast Overlain by Clayey
}

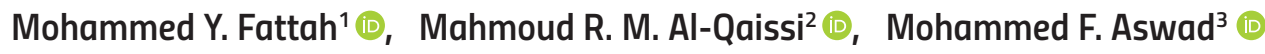

\begin{abstract}
Air transportation development is strictly related to airport competitiveness, since the airport management seeks to improve the capacity to produce services, increase passenger and aircraft movement, improve revenues from aeronautical and non-aeronautical activities, and optimise the other items related to the competitiveness of this type of organisation. In this sense, this study seeks to identify variables associated with the competitiveness of airports, based on their infrastructures, operations, and locations, which can influence the decision-making of airport managers continuously and efficiently. An analysis of the seven busiest Brazilian airports, in terms of aircraft and passenger movement, has been made, and multivariate data analysis has been used through a multiple regression, verifying the relationship between the variables of airports competitiveness, such as the total area of the airport site, number of aircraft parking positions, number of airlines, quantity of aircraft movementlandings and takeoffs, total number of passengers and the GDP of the city where the airport under study is located. The results present an index of competitiveness for each airport analysed after the data mathematical treatment, showing the coefficients at the general equations form aircraft and passenger movement.
\end{abstract}

Keywords: Air Transport, Competitiveness Index, Mathematical Modelling

1 Corresponding author: Mohammed Y. Fattah, Civil Engineering Department, University of Technology, Baghdad, Iraq. E-mail: myf_1968@yahoo.com, ORCID: 0000-0002-4356-651X

2 Mahmoud R. M. Al-Qaissi, Civil Engineering Department, University of Technology, Baghdad, Iraq. ORCID: 0000-0003-0074-9882

3 Mohammed F. Aswad, Civil Engineering Department, University of Technology, Baghdad, Iraq. E-mail: mohammad_aswad@yahoo.com, ORCID: 0000-0002-9761-3895

Citation: Fattah, Y.M., Al-Qaissi, M.R.M. \& Aswad, M.F. (2020). Settlement of railway track on reinforced ballast overlain by clayey. Journal of Transportation and Logistics, 5(2), 105-128. https://doi.org/10.26650/JTL.2020.0014 


\section{Introduction}

Railroad ballast consists of open graded crushed stone used as a bed for railroad track to provide stability. It plays a significant role in providing vertical and lateral support for the track base and distributing the load to the weaker subgrade below. Ballast also helps with drainage, which is an important factor for any type of transportation structure, including railroads.

Track maintenance operations are very time consuming and costly. In addition, trains have become much heavier and faster than in the past, while track conditions have not been substantially improved. The primary potential advantage of geogrids is to extend the maintenance cycle through reinforcement of the ballast. It is also possible to reinforce the sub-ballast which increases the bearing capacity of soft subgrade.

Oxford University carried out model footing experiments to investigate the benefit of reinforcing a granular layer over soft clay. The test consistently demonstrated a $40 \%$ improvement in bearing capacity. It was concluded that the interlocking mechanism of the polymer grid resisted tensile strains preventing lateral movement of particles in the loaded area (Milligan and Love, 1984). Data from the test indicated that the mean angle of load spread increased from 38 degrees in the unreinforced case to more than 50 degrees with a polymer grid. It was concluded that a reinforced granular layer can reduce construction thickness by approximately $50 \%$ to achieve a similar stress on the subgrade.

Research carried out at the University of Waterloo, Canada, showed a 300\% increase in the number of load applications in reinforced pavement. In their tests, asphalt pavement sections were laid over a granular base layer. A test load of $40 \mathrm{kN}$ applied via a $300 \mathrm{~mm}$ diameter circular plate was used representing a standard $80 \mathrm{kN}$ design axle (Haas et al., 1988). It was observed that a $200 \mathrm{~mm}$ reinforced section sees a threefold increase in load applications to reach a given settlement. Interestingly, the $100 \mathrm{~mm}$ reinforced section performed as well as the $200 \mathrm{~mm}$ control. The test was performed with CBRs ranging from 0.5 to $8 \%$. This validates the results over a range of subgrade conditions.

In the mid-1980s, the United Kingdom's Transport and Road Research Laboratory (TRRL - now known as TRL) investigated the effect of polymer grid reinforcement on rut depth. Comparable findings to those of the University of Waterloo were obtained. Geogrid reinforcement for a given sub-base thickness carried 3.5 times more traffic.

Chan (1990) did a series of full-scale experiments to investigate the influence of Geosynthetics on the permanent deformation characteristics of granular bases in pavement. In his experiments, different types and stiffnesses of Geosynthetics were considered as well as varying placement levels in the granular base. It was concluded that the permanent deformation resistance of most geosynthetic-reinforced granular bases was improved. The improvement level depends largely on the quality and thickness of the granular base as well as the location of the geosynthetic within the base.

For weak granular bases, e.g. low elastic stiffness, such as those constructed of sand and gravel, a significant improvement in permanent deformation resistance was achieved with 
the introduction of a polymer grid. The effect is most obvious with the grid installed either in the middle or at the bottom of the layer. A stiffer grid also produced better results with the large vertical deformations and high stresses which Chan applied to this granular base.

Chan concluded that there is minimal benefit if the geosynthetic is placed too far down in the layer. In his opinion, placing geosynthetics at the middle of a base layer, not exceeding $200 \mathrm{~mm}$ depth, gives an optimum improvement. Chan also noted that geogrid performs better than geotextile in terms of reducing permanent deformation, even where it has a lower stiffness. He attributed this to the interlocking effect of the geogrid.

Raymond (2001) studied the behavior of reinforced ballast subjected to repeated loading. The performance of a thin layer of granular material, reinforced and unreinforced was studied, when acting as a foundation material under repeated loading. Compressibility of the subgrade was varied through the use of rubber layers. Raymond concluded that grid reinforcement reduces plastic settlement by $13-30 \%$. It was noted that a bigger improvement was observed when the foundation was weak. It was later deduced that the inclusion of a geogrid on railway track bed can extend the existing 3-month maintenance cycle to a cycle of over 3 years.

Chen (2007) carried out four series of tests, small-scale laboratory tests on silty clay soil, small scale laboratory tests on sandy soil, small-scale laboratory tests on Kentucky crushed limestone, and large-scale field tests on silty clay embankment soil. The influences of different variables and parameters contributing to the improved performance of reinforced soil foundation (RSF) were examined. The investigated parameters included top layer spacing $(u)$, number of reinforcement layers $(N)$, vertical spacing between reinforcement layers $(h)$, tensile modulus and type of reinforcement, embedment of the footing $(D f)$, shape of footing, and type of soil. An axisymmetric finite element analysis with three series of reinforcement layout strategies was performed to study the scale effect on the results of model footing tests. It was found that the inclusion of reinforcement generally resulted in increasing the ultimate bearing capacity of soils and reducing the footing settlement. The optimum depth for the first reinforcement layer was estimated to be at about $0.33 \mathrm{~B}$ (B is the footing width) below the footing for all soil types tested in the study. The bearing capacity of reinforced soil increases in tandem with reinforcement layers (at the same vertical spacing). However, the significance of an additional reinforcement layer decreases with the increase in the number of layers. The reinforcing effect becomes negligible below the influence depth. The influence depth of reinforced sand was obtained at approximately $1.25 \mathrm{~B}$ in this study, regardless of the type of reinforcement and footing embedment depth, while the influence depth of geogrid and geotextile reinforced silty clay was obtained at about $1.5 \mathrm{~B}$ and $1.25 \mathrm{~B}$, respectively. The bearing capacity ratio $(\mathrm{BCR})$ decreases with increasing vertical spacing of reinforcement layers. Geogrid beyond the effective length (4.0 6.0B) results in insignificant mobilized tensile strength, and thus provides negligible reinforcement benefit. The inclusion of reinforcement will redistribute the applied load to a wider area, thus minimizing stress concentration and achieving a more uniform stress distribution, and thus improving the bearing capacity of soil. 
Abu-Farsakh et al. (2008) made a series of laboratory model tests on silty clay embankment soil. The aim of the study was to investigate the potential benefits of using the reinforced soil foundations to improve the bearing capacity and reduce the settlement of shallow foundations on soils. The influences of different variables and parameters contributing to the improved performance of reinforced soil foundation were examined in these tests. The test results showed that the inclusion of reinforcement can significantly improve the soil's bearing capacity and reduce the immediate footing settlement. The geogrids with higher tensile modulus performed better than geogrids with lower tensile modulus. The strain developed along the reinforcement is directly related to the settlement, and therefore higher tension would be developed for geogrid with higher modulus under the same footing settlement. The test results also showed that the inclusion of reinforcement will redistribute the applied load to a wider area, thus minimizing stress concentration and achieving a more uniform stress distribution.

Heidari and El Naggar, (2010) investigated the effect of the soil reinforcement on the performance characteristics for different configurations of shock absorbing foundations. The results showed that soil reinforcement can be used to increase the stiffness of the supporting medium. This increase can be designed to achieve a superior dynamic performance for shock-producing equipment when the mounting system alone cannot achieve a satisfactory design. It was shown that for small hammers, that the reinforced soil foundation can reduce the foundation response amplitude by up to $80 \%$. For large hammers and presses, the reinforced soil foundation can be designed to reduce the foundation response by up to $60 \%$ in the case of no soil reinforcement.

Fattah et al., (2010) analyzed a strip footing resting on a reinforced granular trench by the finite element method. The angle of friction of the trench soil, the modulus of elasticity of the reinforcement material, the depth, width and shape of the granular trench, the locations, and number of the reinforcement layers were studied. The results showed that using a granular trench beneath foundations will increase the bearing capacity and reduce the settlement. Moreover, using polymers as a reinforcement material has a significant effect on both bearing capacity and settlement.

Hayano et al., (2013) studied the effects of ballast thickness and tie-tamper repair on the settlement characteristics of ballasted tracks by conducting a series of cyclic loading tests on model grounds. Results suggest that the $250 \mathrm{~mm}$ ballast thickness, currently adopted as the standard design, is ineffective for minimizing settlement that occurs when the nonlinearity of roadbed compressibility is relatively moderate. Moreover, characteristics of the initial settlement process are altered significantly after tie-tamper implementation, although the degree of gradual subsidence undergoes minimal change regardless of ballast thickness and roadbed type.

Geeta et al., (2013) studied soil- foundation interaction by modeling a square footing to investigate the effect of different types of geogrid on settlement, contact pressure and elastic strain. Performance levels of geogrids made from three different types of polymer have been tested. These polymers are: polypropylene (PP), polyester (PET) and non-polymer (NP).. An analysis was carried out by using the computer software 
program ANSYS with a two dimensional linear 8-noded isoperimetric element. The results indicated that at ratio $(\mathrm{u} / \mathrm{B}=2)$, the contact pressure and elastic strain values become insignificant for two-layered reinforced soil conditions (where $\mathrm{u}$ is the depth of the first reinforcing layer from the base of the footing and B is the footing width). Geogrid efficiency increases with the increased thickness of the geogrid reinforcement up to a certain limit. When the increase in thickness goes beyond the ratio $\mathrm{h} / \mathrm{B}=1$, the reduction in settlement is marginal (where $\mathrm{h}$ is the spacing between reinforcing layers). Using the geogrid made from polypropylene (PP), the reduction in settlement value, contact pressure value as well as elastic strain value were found to be consistently higher as compared to other two cases (PET and NP).

Extensive laboratory tests were conducted by Fattah et al. (2019) to investigate the effect of load amplitude, geogrid position, number of geogrid layers, thickness of ballast layer and clay stiffness on the behavior of the reinforced ballast layer and induced strains in a geogrid. A half-scale railway was constructed for carrying out the tests. It was concluded that the amount of settlement increased as the simulated train load amplitude increased, and there was a sharp increase in settlement up to cycle 500. The increased amount in settlement depended on the presenceof the geogrid and other parameters studied. The transmitted average vertical stress for ballast thicknesses of $30 \mathrm{~cm}$ and $40 \mathrm{~cm}$ increased as the load amplitude increased, regardless of the ballast reinforcement for both soft and stiff clay. The position of the geogrid had no significant effect on the transmitted stresses. The value of the soil pressure and pore water pressure on ballast thicknesses of $20 \mathrm{~cm}$ was higher than for $30 \mathrm{~cm}$ and $40 \mathrm{~cm}$ thicknesses. This meant that the ballast attenuated the induced waves. The soil pressure and pore water pressure for reinforced and unreinforced ballast was higher in stiff clay than in soft clay.

The objective of the present study is to understand the mechanics of geogrid reinforced ballast degradation resting on clayey soil. The research is directed at investigating the benefits of using geogrid reinforcement in minimizing the rate of deterioration of ballasted rail track geometry resting on clayey soil due to dynamic load, and to explore the effect of load amplitude and the position of geogrid layer in ballast layer on the parameters mentioned up on.

The novelty of this study is experimental exploration of the advantages of utilizing geogrid as reinforcement to minimize the amount of degradation of ballast under railway track bases resting on clayey soil.

\section{Laboratory Work and Model Preparation}

The laboratory test work consists of laboratory model tests to investigate the reduction in the compressibility and stress distribution induced in soft clay under a ballast railway reinforced by geogrid reinforcement subjected to dynamic load. An experimental model based on an approximate half scale for general rail track engineering practices, currently used in Iraqu railways, was adapted for this study. The investigated parameters are load amplitude, geogrid position, number of geogrid layers and thickness of ballast layer. 


\subsection{Soil and materials used}

Brown clayey soil was brought from a site in Baghdad. Standard tests were performed to determine the physical properties of the soil. Details are given in Table 1. Grain size distribution of the soil used is shown in Figure 1. According to the Unified Soil Classification System (U.S.C.S.), the soil is classified as CL. A consolidation test was performed for soft and stiff clay states. Table 2 lists the consolidation test results for both soil states.

The ballast was obtained from a private crushed stone factory. It was produced as a result of crushing big stones; the ballast is of white color with angular shapes. Particle size distribution is shown in Figure 2 and the effective size, uniformity coefficient and coefficient of gradation are listed in Table 3 . The ballast is of uniform size with poorly graded gradation (GP) according to the .U.S.C.S.

The geogrid used in all tests was manufactured by Tensar type SS2( Figure 3a.) Its engineering properties are shown in Table 4 , as provided by the manufacturing company. The sheet of geogrid was used from test to test but was replaced whenever it became visibly overstressed or damaged, as shown in Figure $3 b$.

Table 1. Physical properties of used clay.

\begin{tabular}{|l|c|c|}
\hline Test & Value & Specification \\
\hline Liquid Limit (LL), \% & 46 & ASTM D 4318-00 \\
\hline Plastic Limit (PL), \% & 21 & ASTM D 4318-00 \\
\hline Plasticity Index, $\%$ & 25 & ASTM D 4318-00 \\
\hline Specific gravity (Gs) & 2.65 & ASTM D854-00 \\
\hline Gravel $\%,>4.75, \mathrm{~mm}$ & 0 & ASTM D 422-00 \\
\hline Sand $\%, 0.075-4.75, \mathrm{~mm}$ & 4 & ASTM D 422-00 \\
\hline Silt $\%, 0.005-0.075, \mathrm{~mm}$ & 37 & ASTM D 422-00 \\
\hline Clay $\%,<0.005 \mathrm{~mm}$ & 59 & ASTM D 422-00 \\
\hline
\end{tabular}

Table 2. Consolidation test results for soft and stiff clay.

\begin{tabular}{|l|c|c|}
\hline Parameter & Soft State & Stiff State \\
\hline Undrained shear strength, $\mathrm{C}_{\mathrm{u}}$ & $20-25 \mathrm{kN} / \mathrm{m}^{2}$ & $\approx 50 \mathrm{kN} / \mathrm{m}^{2}$ \\
\hline Initial void ratio, $\mathrm{e}_{\mathrm{o}}$ & 0.61 & 0.38 \\
\hline Dry unit weight, $\gamma_{\text {dry }}$ & 16.6 & 19.3 \\
\hline Saturated unit weight, $\gamma_{\mathrm{sat}}$ & 21.6 & 23.4 \\
\hline Compression index, $\mathrm{C}_{\mathrm{c}}$ & 0.18 & 0.1 \\
\hline Swelling index, $\mathrm{C}_{\mathrm{r}}$ & 0.1 & 0.05 \\
\hline
\end{tabular}


Table 3. Ballast particle size characteristics.

\begin{tabular}{|l|c|}
\hline Parameter & Value \\
\hline $\mathrm{D}_{60}, \mathrm{~mm}$ & 21.59 \\
\hline $\mathrm{D}_{30}, \mathrm{~mm}$ & 20.61 \\
\hline $\mathrm{D}_{10}, \mathrm{~mm}$ & 18.35 \\
\hline Coefficient of uniformity, $\mathrm{C}_{\mathrm{u}}$ & 1.18 \\
\hline Coefficient of gradation, $\mathrm{C}_{\mathrm{c}}$ & 1.07 \\
\hline$\gamma_{\text {dry min }}, \mathrm{kN} / \mathrm{m}^{3}$ & 10.21 \\
\hline$\gamma_{\text {dry max }}, \mathrm{kN} / \mathrm{m}^{3}$ & 11.25 \\
\hline$\gamma_{\text {used }}, \mathrm{kN} / \mathrm{m}^{3}$ & 10.92 \\
\hline Relative Density & $70 \%$ \\
\hline
\end{tabular}

Table 4. Tensar SS2 geogrid specification.

\begin{tabular}{|c|c|c|}
\hline Property & Units & \\
\hline Polymer (1) & & PP \\
\hline Minimum carbon black (2) & $\%$ & 2 \\
\hline Roll width & $\mathrm{m}$ & 4.0 \\
\hline Roll length & $\mathrm{m}$ & 50 \\
\hline Unit weight & $\mathrm{kg} / \mathrm{m}^{2}$ & 0.29 \\
\hline Roll weight & $\mathrm{Kg}$ & 60 \\
\hline \multicolumn{3}{|l|}{ Dimensions } \\
\hline $\mathrm{A}_{\mathrm{L}}$ & $\mathrm{mm}$ & 28 \\
\hline $\mathrm{A}_{\mathrm{T}}$ & $\mathrm{mm}$ & 40 \\
\hline $\mathrm{W}_{\mathrm{LR}}$ & $\mathrm{mm}$ & 3.0 \\
\hline $\mathrm{W}_{\mathrm{TR}}$ & $\mathrm{mm}$ & 3.0 \\
\hline$t_{J}$ & $\mathrm{~mm}$ & 3.8 \\
\hline$t_{L R}$ & $\mathrm{~mm}$ & 1.2 \\
\hline$t_{T R}$ & $\mathrm{~mm}$ & 0.9 \\
\hline Rib shape & \multicolumn{2}{|c|}{ Rectangular } \\
\hline \multicolumn{3}{|c|}{ Quality Control Strength (longitudinal) } \\
\hline $\mathrm{T}_{\text {ult }}(3)$ & $\mathrm{kN} / \mathrm{m}$ & 17.5 \\
\hline Load at $2 \%$ strain (3) & $\mathrm{kN} / \mathrm{m}$ & 7.0 \\
\hline Load at $5 \%$ strain $(3)$ & $\mathrm{kN} / \mathrm{m}$ & 14.0 \\
\hline Approx. strain at $\mathrm{T}_{\text {ult }}$ & $\%$ & 12.0 \\
\hline \multicolumn{3}{|c|}{ Quality Control Strength (transverse) } \\
\hline $\mathrm{T}_{\text {ult }}(3)$ & $\mathrm{kN} / \mathrm{m}$ & 31.5 \\
\hline Load at $2 \%$ strain (3) & $\mathrm{kN} / \mathrm{m}$ & 12.0 \\
\hline Load at $2 \%$ strain (3) & $\mathrm{kN} / \mathrm{m}$ & 23.0 \\
\hline Approx. strain at $\mathrm{T}_{\text {ult }}$ & $\%$ & 10.0 \\
\hline \multicolumn{3}{|c|}{ Junction strength as \% of QC strength (4) } \\
\hline Minimum junction strength & $\%$ & 90 \\
\hline
\end{tabular}

(1) PP denotes polypropylene. 


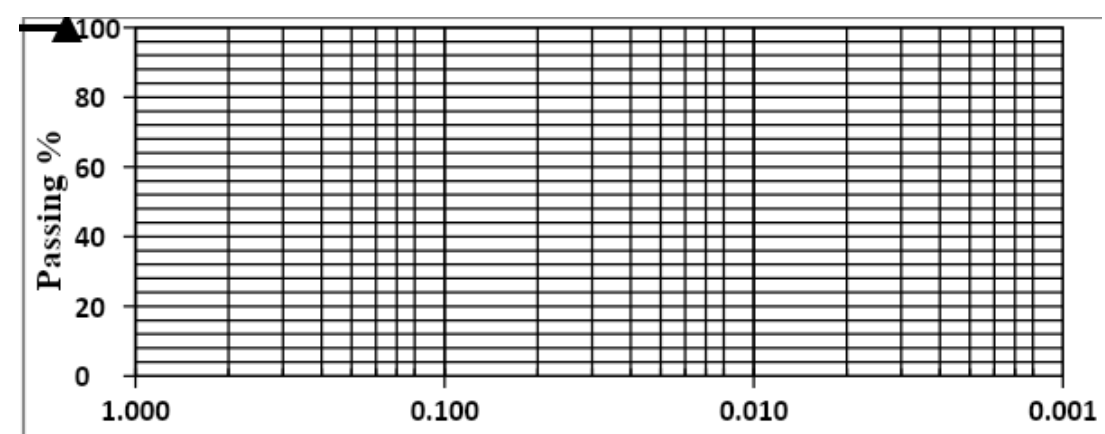

Figure 1. Grain size distribution for the clay.

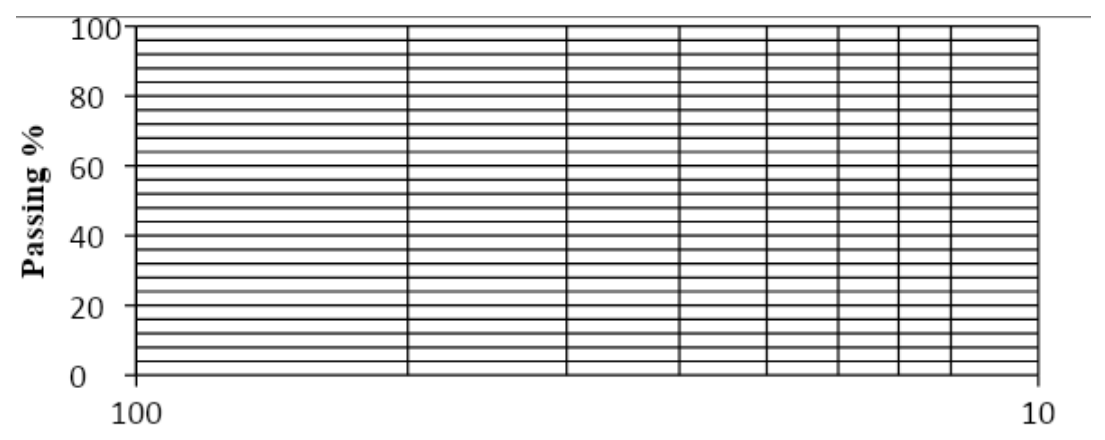

Figure 2. Grain size distribution for the ballast.

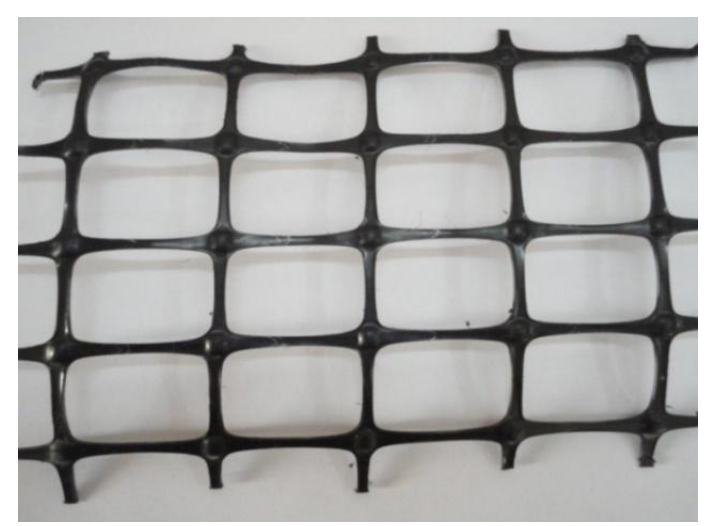

a. Before test.

Figure 3. Geogrid reinforcement used.



b. Damage in geogrid reinforcement used

\subsection{Model tests}

\subsubsection{Load setup design and manufacturing}

To study the response of the railway loads on soft clay, it was necessary to simulate the conditions as close as possible to those occurring in the field. To achieve this aim, a special testing apparatus and other accessories were designed and manufactured. The apparatus had the capability of applying different dynamic loads under different frequencies.

The general view of the apparatus is shown in Figures 4 and 5.

The apparatus consists of the following: 
Loading steel frame. 2. Hydraulic loading system. 3. Load spreader beam. 4. Data acquisition. 5. Shaft encoder. 6. Steel container.

\subsubsection{Loading steel frame}

To support and ensure the verticality of the hydraulic jack used in applying the central concentrated load, a steel frame was designed and constructed. The steel frame consisted mainly of four columns and four beams. Each column and beam was made of steel with a square cross section area of $100 \mathrm{~mm} \times 100 \mathrm{~mm}$, and is $4 \mathrm{~mm}$ thick. The dimensions of the steel frame (length $\times$ width $\times$ height) were $1700 \mathrm{~mm} \times 700 \mathrm{~mm} \times 1700 \mathrm{~mm}$. To strengthen the steel frame, two vertical steel channels were welded.

A $20 \mathrm{~mm}$ thick steel plate with dimensions of $700 \mathrm{~mm} \times 500 \mathrm{~mm}$ was welded on the center of the frame in order to carry the hydraulic jack and the settlement measurement device (Encoder). The steel frame was fixed to the floor using four base plates of dimension 200 $\mathrm{mm} \times 200 \mathrm{~mm} \times 20 \mathrm{~mm}$. Each base plate was fixed to the floor using four bolts.

\subsubsection{Hydraulic loading system}

As shown in Figure 6, the system consisted of a hydraulic steel tank with a capacity of 70 liters. The tank consisted of two holes; the upper one was used to fill the oil and the lower one is for discharge. The tank consisted of a gear type hydraulic pump with a fixed geometrical volume giving a discharge about 12 liter/min with a maximum pressure of 150 bars. The axis of the pump was connected by a coupling with a three phase electrical rotary motor of $3 \mathrm{hp}$ capacity and $1450 \mathrm{rpm}$ rotation speed. The pump and the motor were fixed in housing on the upper surface of the tank.

During the rotation of the pump, it sent the hydraulic through a flexible hose to a distributional block where there were two directional valves fixed to it, the first one which worked in one direction was used as a key to lock the hydraulic in the system or send it back to the tank. This hydraulic valve was connected with another directional valve which controlled the moving of the hydraulic cylinder jack up and down (Figure 6). The movement of the hydraulic cylinder jack was controlled electrically by a programmable logic control (PLC), through which the movement (up and down) could be controlled by choosing the hearts that we need to control data acquisition. The data acquisition also displays the load magnitude that was applied on the rail. An $80 \mathrm{~cm} \times 5 \mathrm{~cm} \times 5 \mathrm{~cm}$ solid steel beam was used to apply the load on the track panel as shown in Figure 7.

The tests were carried out in a steel container with plan dimensions of $1.5 \mathrm{~m}$ length $\times 1$ $\mathrm{m}$ width $\times 1 \mathrm{~m}$ height. Each part of the container is made of a $5 \mathrm{~mm}$ thick steel plate. The container is made of five welded parts, one for the base and others for the four sides of the container. The long sides were braced externally by angles at their edges.

\subsubsection{Data acquisition}

Data acquisition was used to measure and sense the occurring displacement during the tests, which enabled the tests to obtain a large amount of data in a very short time. Moreover, it was used to choose the specified frequency used in the test. 
The data acquisition was done using Programmable Logic Controller (PLC), which can be defined as a digital computer used for electro-mechanical automation processes, and it is a high-tech processing unit. This type of system analyzes the data digitally.

The program of Programmable Logic Controller (PLC) is executed repeatedly whenever the controlled system is running and then the data is saved in its memory..

A shaft encoder is an electro-mechanical device used to convert the motion of the shaft to digital code. The output of incremental encoders supply information of the motion of the shaft which is processed into information such as, displacement, revolution per minute (rpm), speed, and position.

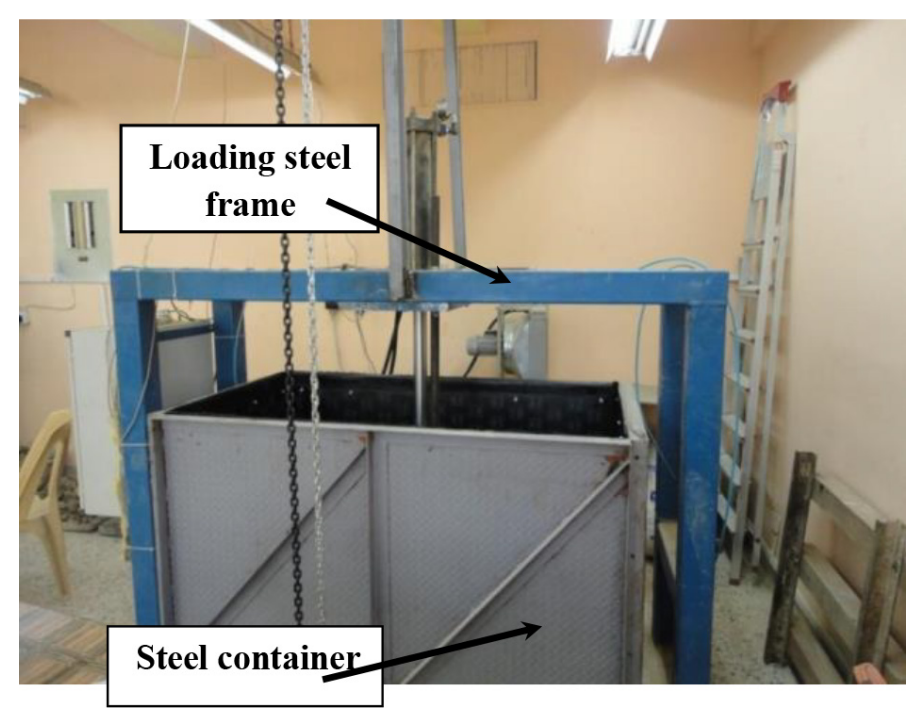

Figure 4. Steel frame of the loading system.

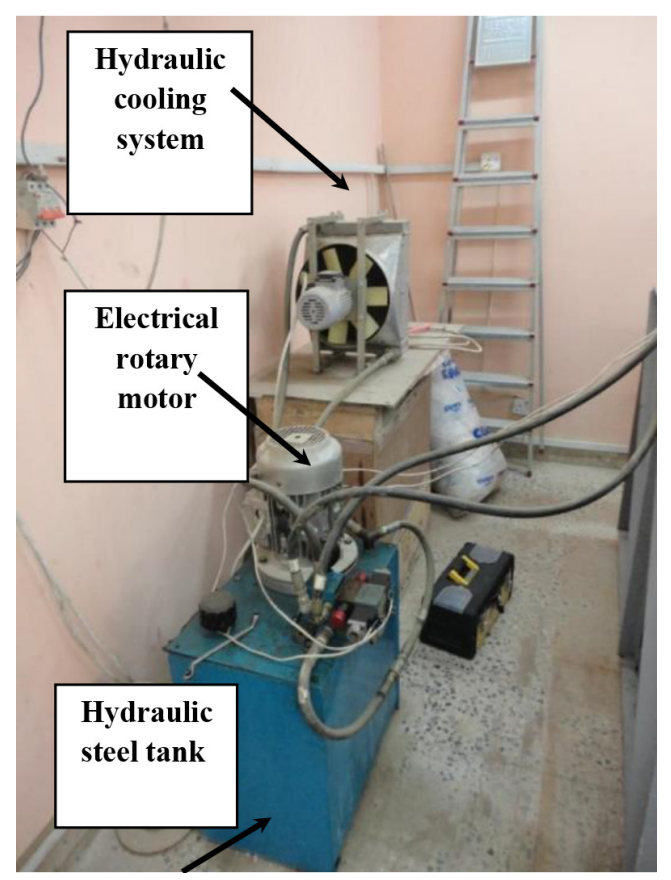

Figure 5. Hydraulic loading system. 


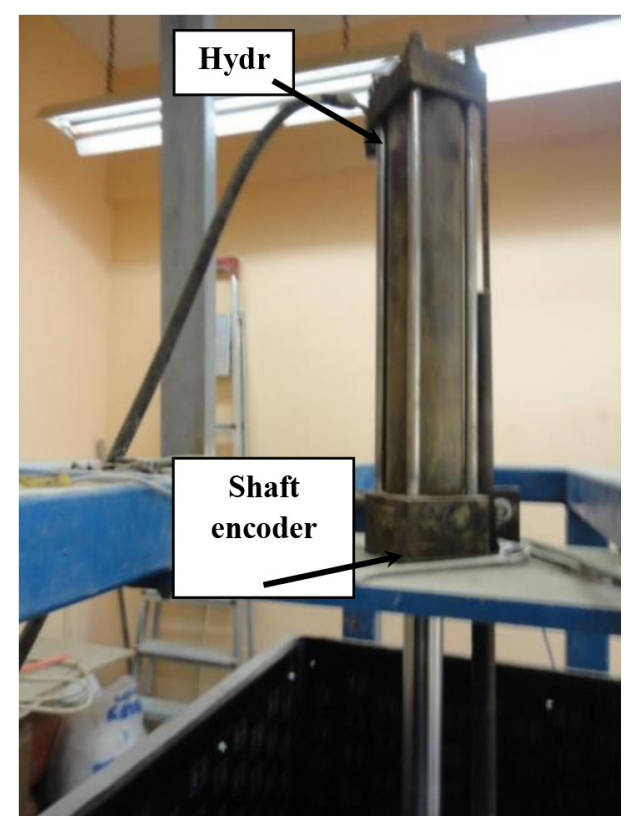

Figure 6. Hydraulic cylinder jack.



Figure 7. Load spreader beam.

\subsubsection{Instrumentation}

A total of four Linear Variable Differential Transformers (LVDTs) were used to instrument the ends of the track panel. The LVDTs were used to measure the surface displacement of the railroad track to check it with the shaft encoder measurement.

\subsection{Model preparation}

\subsubsection{Preparation of bed of soil}

Prior to the preparation of the bed of soil, trial tests were performed to control the efficiency of the method of preparation. These control tests were carried out to check two main important points for the preparation of homogenous soft beds of soil. The first was to determine the variation of undrained shear strength with time at different water amounts 
$(25 \%, 28 \%, 32 \%, 35 \%$ and $40 \%)$. These tests specify the time required for the remolded soil to regain its strength after a rest period following the mixing process. To accomplish this, five samples were prepared individually and placed in three layers in molds. Each layer was tamped gently with a special hammer to extract any entrapped air. The samples were then covered with polythene sheet and left for a period of six days. The undrained shear strength was measured daily by using a portable vane shear device. It was found that the time required for the remolded soil to regain its strength was about three days.

The second test was to determine the variation of shear strength after the three days of mixing versus different liquidity indices. The results of the variation of the undrained shear strength with different liquidity indices are shown in Figure 8.

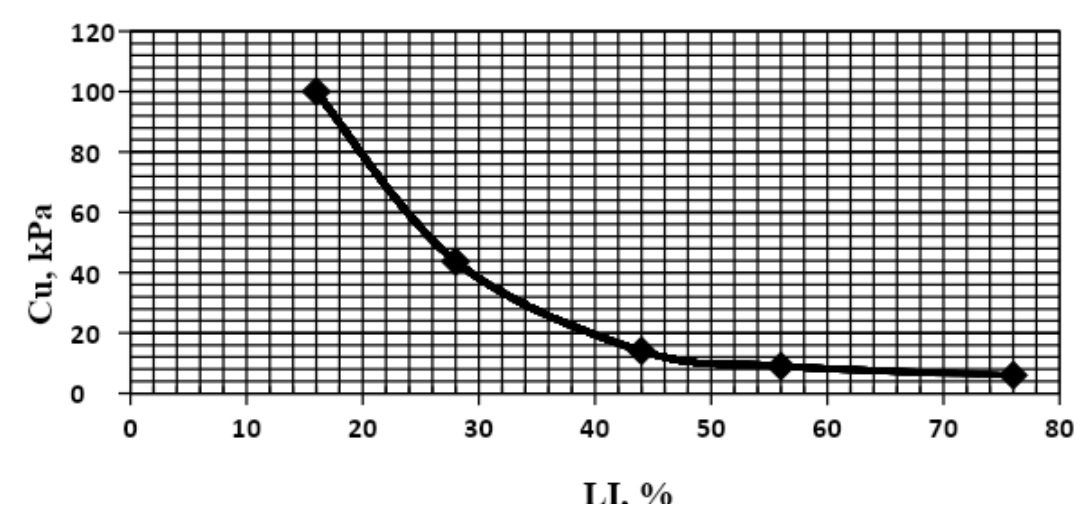

Figure 8. Variation of the undrained shear strength with liquidity index at 3 day curing.

\subsubsection{Preparation of the ballast layer}

The construction of the ballast layer started three days after the preparation of the soil bed. The ballast was placed carefully on the surface of the bed of soil in layers; each layer was not more than $100 \mathrm{~mm}$ thick. A predetermined volume of ballast was prepared which was sufficient to create a uniform layer. Each layer was compressed gently by a tamping rod to attain a placement dry unit weight of about $10.92 \mathrm{kN} / \mathrm{m}^{3}$. This placement unit weight corresponded to a relative density of about $70 \%$.

A half-scale railway was constructed for carrying out the tests. Two rails of $900 \mathrm{~mm}$ in length with three wooden slippers ( $900 \mathrm{~mm}$ x $90 \mathrm{~mm}$ x $90 \mathrm{~mm}$ ) were used to construct the track panel (Figure 9). Three ballast thicknesses of 200, 300 and $400 \mathrm{~mm}$ were used in the tests, each side of the ballast was sloped down on about a 2:1 slope. The ballast was overlying $500 \mathrm{~mm}$ thick clay in both soft and stiff states. The tests were carried out with and without geogrid reinforcement. The angle of the slope of the ballast was controlled by maintaining alignment with markings on the wall of the box.

\subsubsection{Test procedure}

The test was carried out in a well tied steel box of $1.5 \mathrm{~m}$ length $\times 1 \mathrm{~m}$ width $\times 1 \mathrm{~m}$ height. The box was padded with two layers, the first one consisting of compressed styropor sheets $5 \mathrm{~mm}$ thick and the other one of $4 \mathrm{~mm}$ thick rubber to prevent wave reflection during the test. 
The box was filled with relatively soft clay which was placed in $100 \mathrm{~mm}$ layers to ensure the consistency and was compressed by plywood to a depth of $500 \mathrm{~mm}$. After the placement of each layer, it was pressed gently with a wooden tamper in order to remove entrapped air.

The clay material used in the tests had a wet unit weight of $21.6 \mathrm{kN} / \mathrm{m}^{3}$, moisture content of about $30 \%$ and a drained shear strength of about $25 \mathrm{kN} / \mathrm{m}^{2}$. It was placed in the box in its soft state with a wet density of $23.4 \mathrm{kN} / \mathrm{m}^{3}$, moisture content of about $21 \%$ and a drained shear strength about $50 \mathrm{kN} / \mathrm{m}^{2}$. When it was placed in its stiff state, the liquid limit of the clay was found to be $46 \%$ while the plastic limit was $21 \%$.

During preparation of the ballast layer, the geogrid was laid in a predetermined position, as specified in the reinforced ballast tests shown in Figure 10.

The track panel was then placed into its position, using manual chain hoists. A good seating on the surface of the ballast was achieved by tamping it carefully. Special care was given to the levelling of the track panel and sleeper at the position where the rail must be placed (Figure 11). Additional ballast was then added between and at ends of the sleepers to achieve restraint.

After preparing the model for test, it was carried and centered in the load setup and then the load-spreader beam was lowered carefully until it touched the rails. After that, the load and frequency was adjusted by the LCD touch-screen as required and then the test began.

The built-in displacement transducer records a measurement of central track panel displacement once the load comes into contact with the track panel. The jack load was applied through the load-spreader beam, which was connected to the jack in to the track panel and then to the rails and sleepers.

The hydraulic jack and the builtin displacement transducer were connected to control data acquisition. This control data acquisition stores control functions and acquires data. The data acquisition is then connected to a computer, which receives and stores the data.

The traffic loading simulation on the sleepers was executed by applying rectified sine wave loading. This type of loading was suggested by Awoleye (1993). It simulates a running train over three sleepers in which $50 \%$ of the wheel load transmits to the middle sleeper and $25 \%$ of the wheel load on both outer sleepers.

The frequency of loading in the test was up to $2 \mathrm{~Hz}$. This frequency is considered very low when compared to the usual frequency in the track of approximately $8-10 \mathrm{~Hz}$. This frequency, however, was associated with the pressure and flow capacity of the hydraulic loading system.

The effect of applying geogrid reinforcement was examined by the comparison of settlement magnitude, as well as the pressure and pore water pressure developed in the clay layer, which was performed in various tests with and without geogrid in the ballast layer. A flowchart of the testing program is shown in Figure 12. 


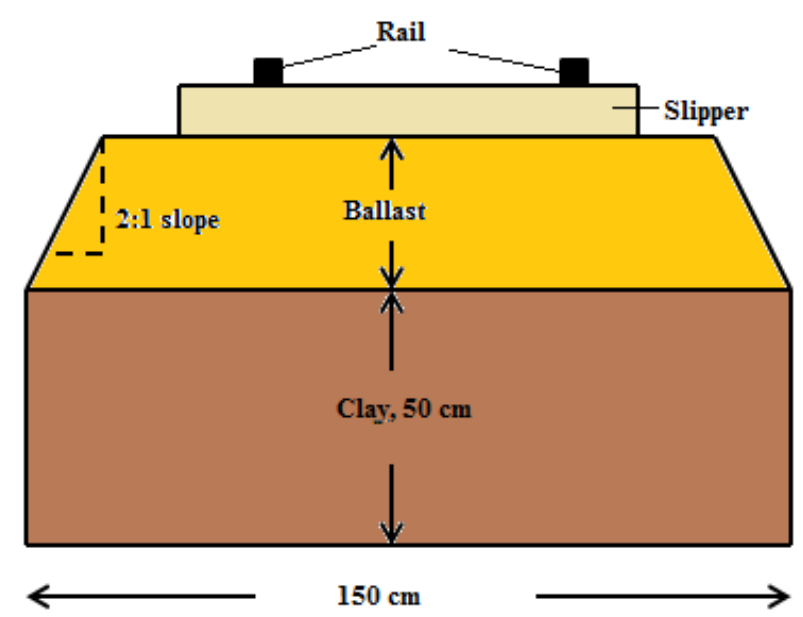

Figure 9. The laboratory test section.

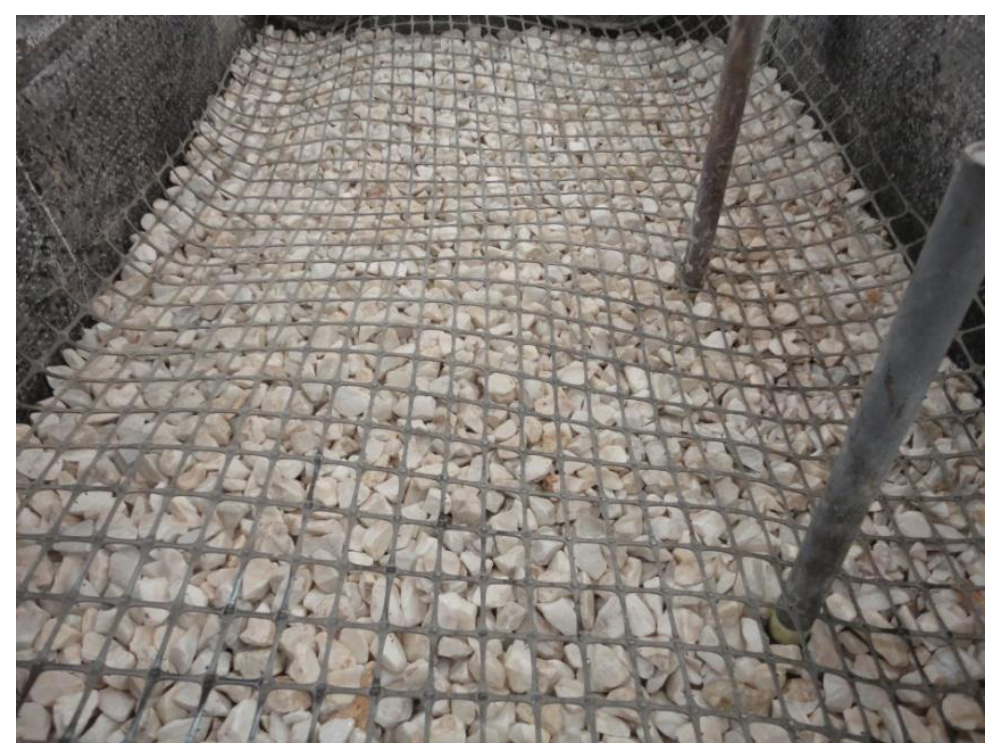

Figure 10. Placing the geogrid.

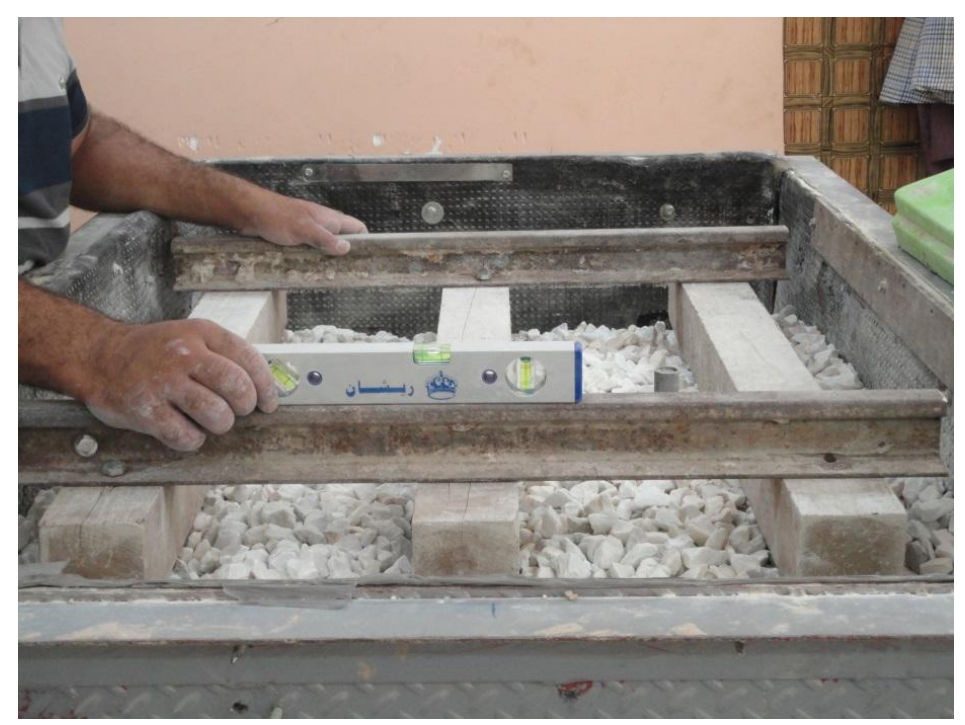

Figure 11. Placing and leveling the track panel. 
$\mathrm{T}=$ Test, $\mathrm{A}=$ Amplitude, $\mathrm{f}=$ frequency, No. $=$ Number of Geogrid Layers



Figure 12. Flowchart of the testing program.

\section{Experimental Results and Interpretation}

This section presents the results of the laboratory tests that were conducted on the halfscale ballasted railway model; the ballast was resting on soft or stiff clay and the ballast was stabilized with geogrid. The model was subjected to a dynamic load by a dynamic load setup to represent the passage of the train on the rail road. Settlement in ballast and clay was investigated in reinforced and unreinforced ballast. The studied parameters were the load amplitude, geogrid position, number of geogrid layers and thickness of the ballast layer.

Figures 13 to 30 show the typical relationship of settlement versus number of cycles for different load amplitudes. In these figures for all sections, to focus only on the effect of the foregoing parameter, the other investigated parameters will be fixed.

The symbols used in the figures are defined as follows:

T: ballast layer thickness for soft clay tests, $\mathrm{cm}$,

ST: ballast layer thickness for stiff clay tests, $\mathrm{cm}$,

DT: ballast layer thickness with sand drains tests, $\mathrm{cm}$,

A: load amplitude, ton,

f: load frequency, $\mathrm{Hz}$,

NL: number of geogrid layers and layer position $(\mathrm{h} / \mathrm{T})$, and

h: position of geogrid layer in ballast layer from the upper surface of the clay layer.

Obviously as seen in these figures, the amount of settlement increased when the load amplitude increased, there was a sharp increase in settlement up to 500 cycles. After 
that, there was a gradual increase, finally levelling out at between 2,500 to 4,500 cycles depending on the load frequency. These findings are consistent with those of Paute et al. (1996) who concluded that "there will be a decrease in the rate of permanent deformation in granular material under repeated loading and that it is possible to derive a limit value for the accumulation of permanent strain."

From the figures, it can be observed that there was little increase in the induced settlement when the load amplitude increased from 0.5 to 1 ton, but it was higher when the load amplitude increased to 2 tons, the increasing amount in settlement depending on the geogrid existence and the other studied parameters.

Figures 31 to 36 present the relationship between the load amplitude and settlement ratio $\mathrm{S} / \mathrm{T}$ (settlement ratio is the cumulative settlement ( $\mathrm{S}$ ) divided by ballast thickness (T)) for soft and stiff clay layers. These figures show that for most cases and in all stages of the tests at low load amplitude ( 0.5 ton), that there was almost equal settlement for reinforced and unreinforced ballast layers. This is because at low load amplitude, the ballast acts as unreinforced material as a result of little strain occurring in the geogrid.

As seen from the figures, the effect of load amplitude on the settlement of the composite in the beginning of the tests was almost negligible with both reinforced and unreinforced ballast layer, so the settlement ratio difference was small between them. It increased with increasing numbers of cycles. This was likely due to ineffective interlocking between the ballast particles and the geogrid at the beginning of the test.

All the figures show that the initial settlement ratio for the 2 ton amplitude varied between $1-2 \%$, while for 0.5 and 1 ton amplitudes, it varied between $0.5-1 \%$. This observation includes reinforced and unreinforced ballast. This likely happened because of the high rearrangement of the ballast particles in the beginning of the test under the 2 ton load amplitude.

From Figures 34 to 36, it can be seen that there was little difference in the effect of load amplitude on the settlement ratio between reinforced and unreinforced ballast with stiff clay at the beginning of the test, especially at low load amplitude. While at 500 cycles and more of the test, especially at high load amplitude, the settlement ratio was lower for the unreinforced ballast than the reinforced. This is likely to happen because in stiff clay subgrade, there is little to no strain happening in the geotextile, which introduces a reduction in the interlocking between the ballast particles and geogrid, and a slip surface may occur at the geogrid surface at high load amplitude, which increases settlement. This is consistent with Rymond, (2001) who noted a large improvement in the grid-reinforced composite system when the foundation soil was weak.

Fattah et al. (2020), from finite element analysis, found that at low speed $(30 \mathrm{~km} / \mathrm{hr})$, about $100 \%$ of the total settlement appeared in the clay layer. After this speed, the percentage in settlement levelled out at about $80 \%$ at the clay layer and $20 \%$ at the ballast layer. For both reinforced and unreinforced models, the settlement percentage was about 95 $\%$ for the clay layer and about $5 \%$ for the ballast layer at $30 \mathrm{~km} / \mathrm{hr}$, as the settlement percentage levelled out at about $80 \%$ for the clay layer and $20 \%$ for the ballast layer for speeds $60 \mathrm{~km} / \mathrm{hr}$ and more. 
The geogrid employs the effect of interlocking between granular particles. The granular particles penetrate the apertures of geogrid and are locked between the strands of geogrid. This mechanism of immobilization of the reinforced particles gives strong shear resistance, which reduces the lateral movement and increases the bearing capacity of the base layer.

As seen in these figures, the effect of load frequency on the settlement ratio was almost constant after 500 cycles. This is due to the total settlement almost reaching its peak value after 500 cycles, which means that the ballast particles became very close to each other, so the load frequency was less effective for the high-contact particle forces.

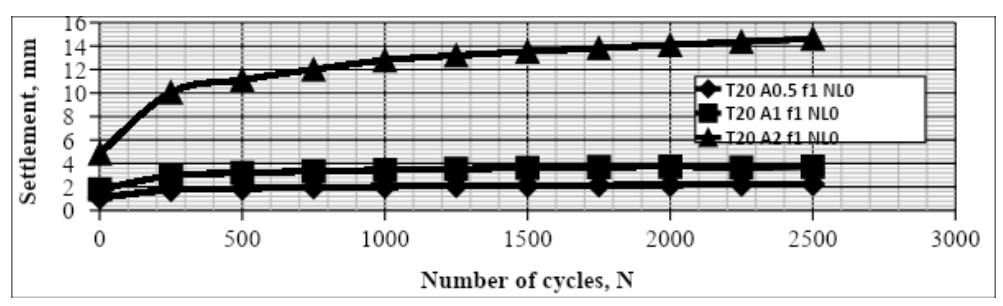

Figure 13. Settlement versus number of cycles for different load amplitudes with ballast thickness $20 \mathrm{~cm}$, frequency $1 \mathrm{~Hz}$ and without reinforcement.

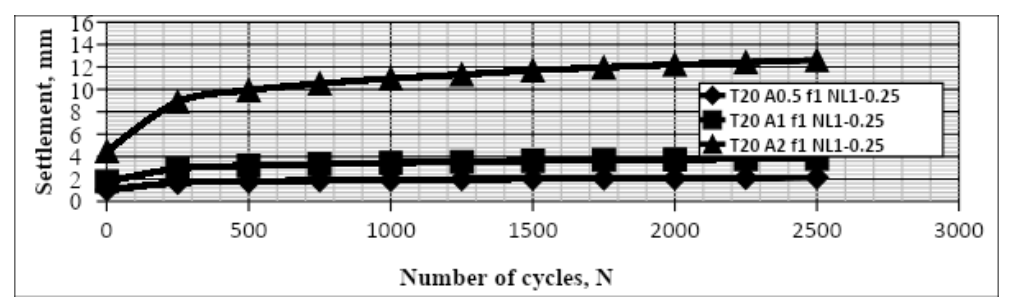

Figure 14. Settlement versus number of cycles for different load amplitudes with ballast thickness $20 \mathrm{~cm}$, frequency $1 \mathrm{~Hz}$ and with one layer reinforcement $\mathrm{h} / \mathrm{T}=0.25$.

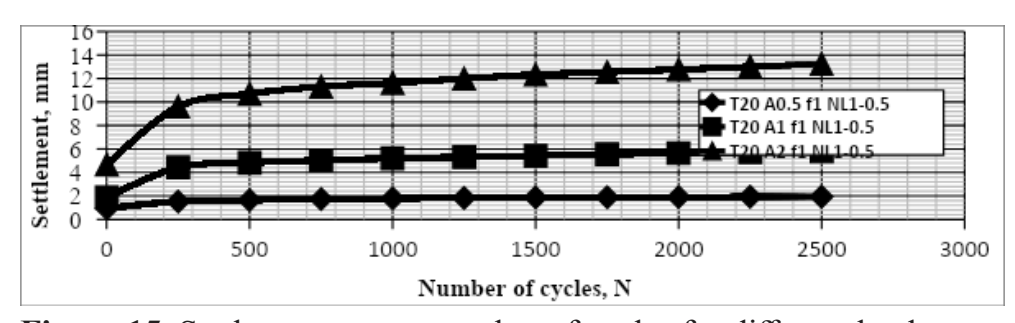

Figure 15. Settlement versus number of cycles for different load amplitudes with ballast thickness $20 \mathrm{~cm}$, frequency $1 \mathrm{~Hz}$ and with one layer reinforcement $\mathrm{h} / \mathrm{T}=0.5$.

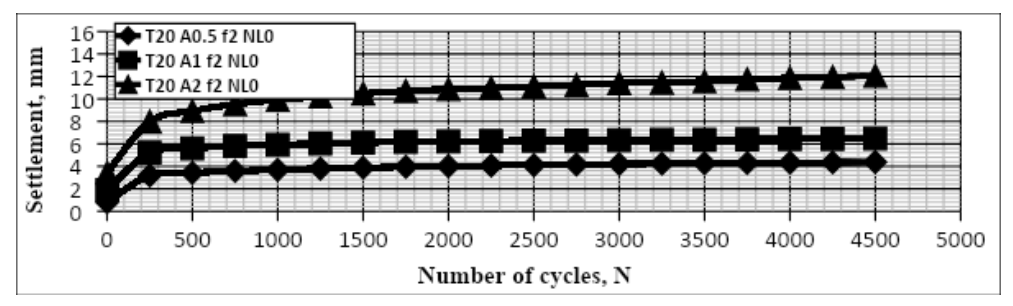

Figure 16. Settlement versus number of cycles for different load amplitudes with ballast thickness $20 \mathrm{~cm}$, frequency $2 \mathrm{~Hz}$ and without reinforcement. 


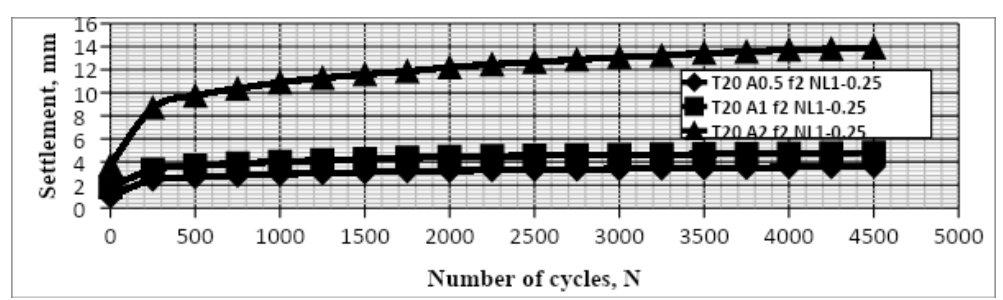

Figure 17. Settlement versus number of cycles for different load amplitudes with ballast thickness $20 \mathrm{~cm}$, frequency $2 \mathrm{~Hz}$ and with one layer reinforcement $\mathrm{h} / \mathrm{T}=0.25$.

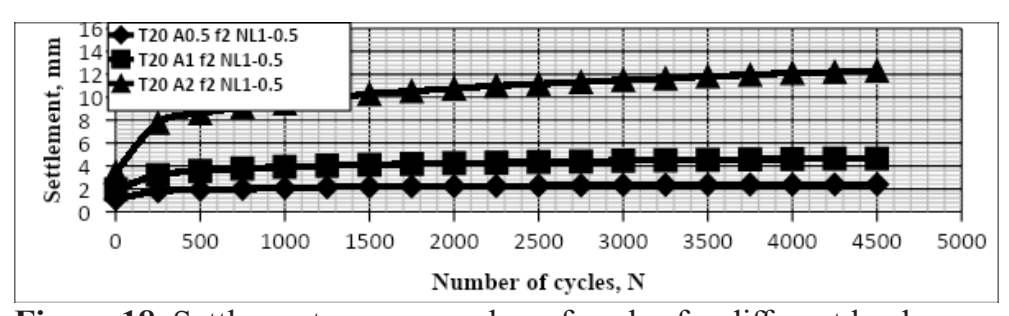

Figure 18. Settlement versus number of cycles for different load amplitudes with ballast thickness $20 \mathrm{~cm}$, frequency $2 \mathrm{~Hz}$ and with one layer reinforcement $\mathrm{h} / \mathrm{T}=0.5$.

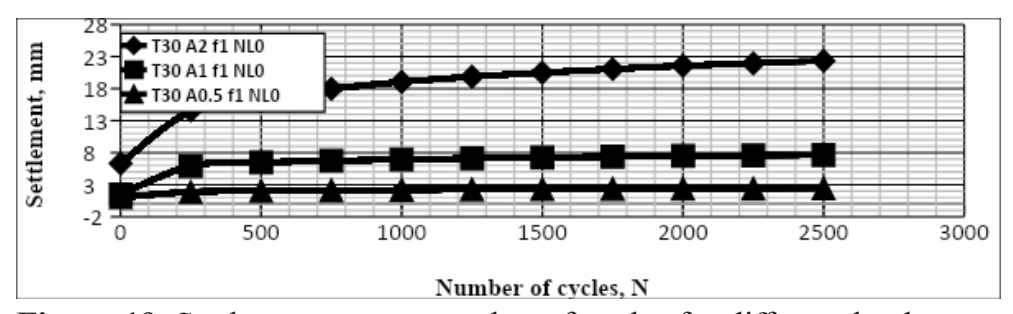

Figure 19. Settlement versus number of cycles for different load amplitudes with ballast thickness $30 \mathrm{~cm}$, frequency $1 \mathrm{~Hz}$ and without reinforcement.

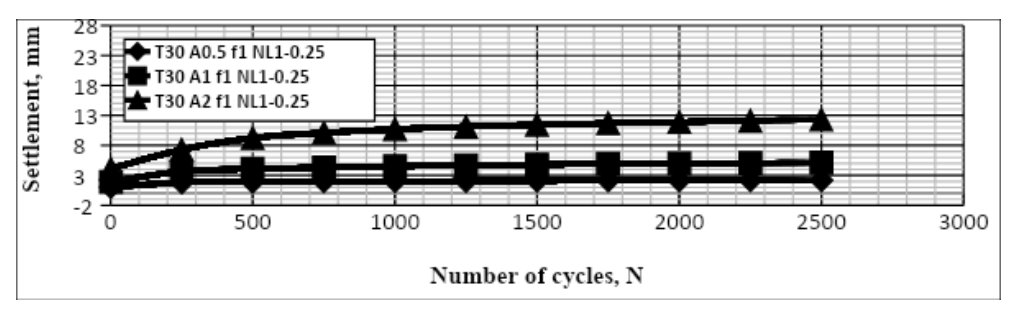

Figure 20. Settlement versus number of cycles for different load amplitudes with ballast thickness $30 \mathrm{~cm}$, frequency $1 \mathrm{~Hz}$ and with one layer reinforcement $\mathrm{h} / \mathrm{T}=0.25$.

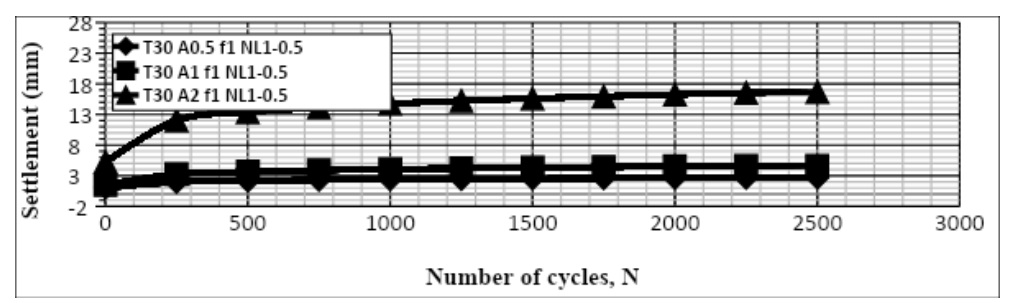

Figure 21. Settlement versus number of cycles for different load amplitudes with ballast thickness $30 \mathrm{~cm}$, frequency $1 \mathrm{~Hz}$ and with one layer reinforcement $\mathrm{h} / \mathrm{T}=0.5$. 


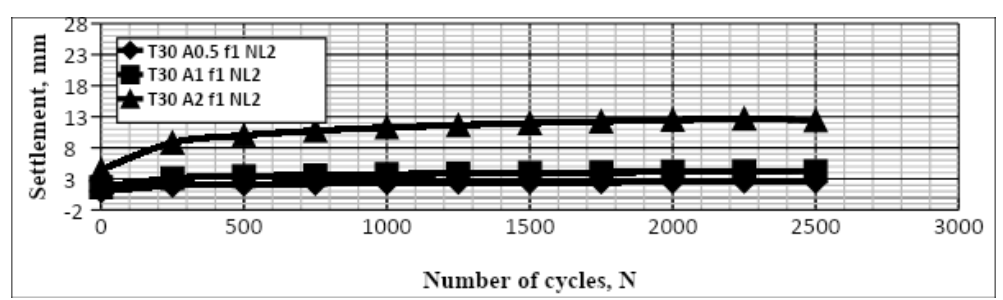

Figure 22. Settlement versus number of cycles for different load amplitudes with ballast thickness $30 \mathrm{~cm}$, frequency $1 \mathrm{~Hz}$ and with two layer reinforcement $\mathrm{h} / \mathrm{T}=0.25$.

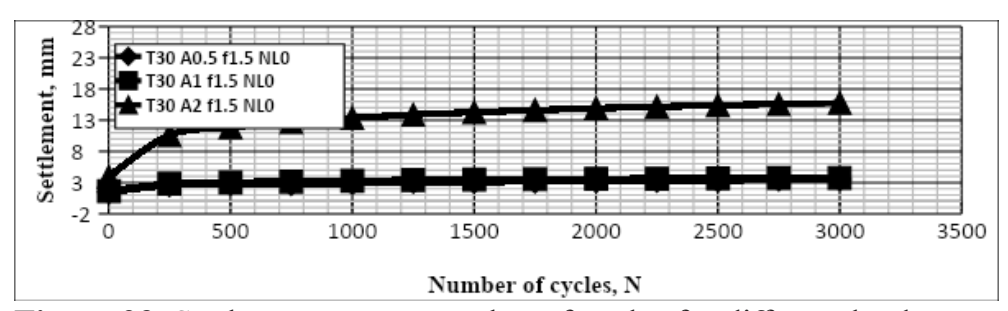

Figure 23. Settlement versus number of cycles for different load amplitudes with ballast thickness $30 \mathrm{~cm}$, frequency $1.5 \mathrm{~Hz}$ and without reinforcement.

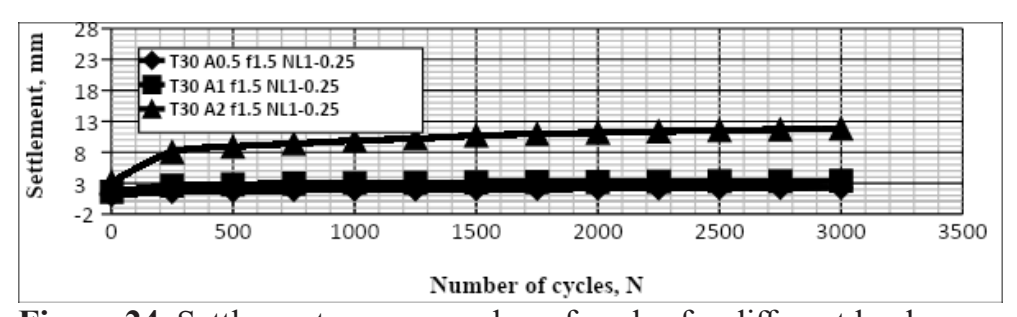

Figure 24. Settlement versus number of cycles for different load amplitudes with ballast thickness $30 \mathrm{~cm}$, frequency $1.5 \mathrm{~Hz}$ and with one layer reinforcement $\mathrm{h} / \mathrm{T}=0.25$.

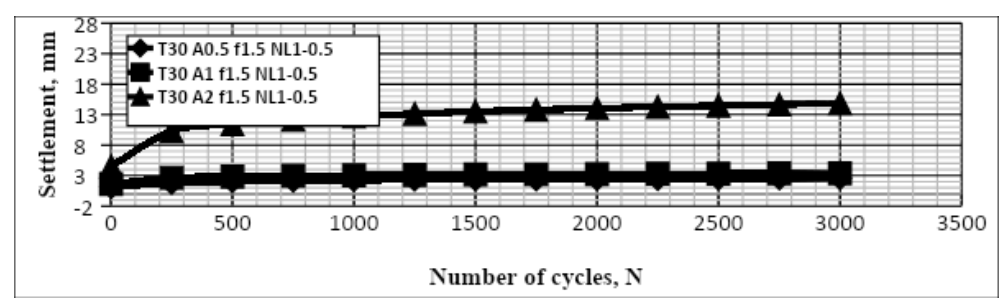

Figure 25. Settlement versus number of cycles for different load amplitudes with ballast thickness $30 \mathrm{~cm}$, frequency $1.5 \mathrm{~Hz}$ and with one layer reinforcement $\mathrm{h} / \mathrm{T}=0.5$.

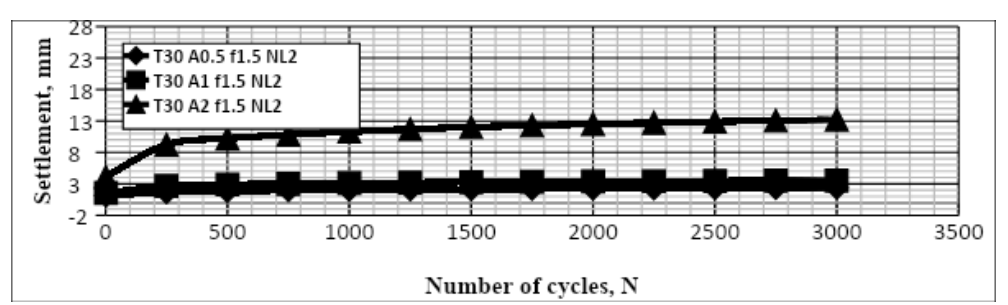

Figure 26. Settlement versus number of cycles for different load amplitudes with ballast thickness $30 \mathrm{~cm}$, frequency $1.5 \mathrm{~Hz}$ and with Two layer reinforcement $\mathrm{h} / \mathrm{T}=0.25$. 


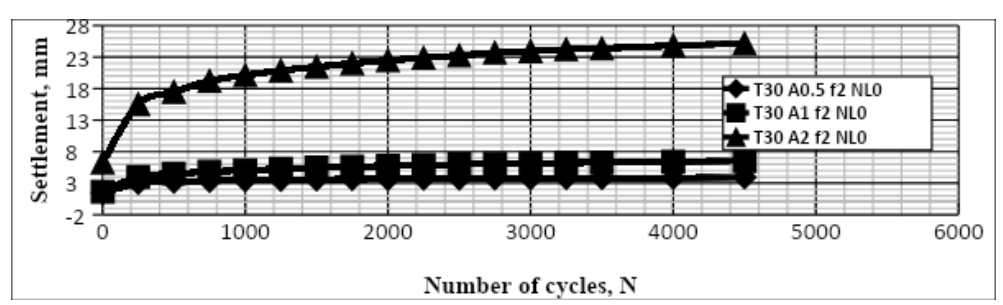

Figure 27. Settlement versus number of cycles for different load amplitudes with ballast thickness $30 \mathrm{~cm}$, frequency $2 \mathrm{~Hz}$ and without reinforcement.

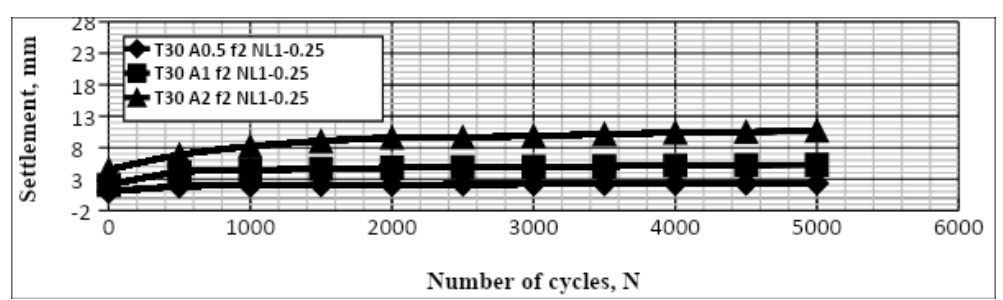

Figure 28. Settlement versus number of cycles for different load amplitudes with ballast thickness $30 \mathrm{~cm}$, frequency $2 \mathrm{~Hz}$ and with one layer reinforcement $\mathrm{h} / \mathrm{T}=0.25$.

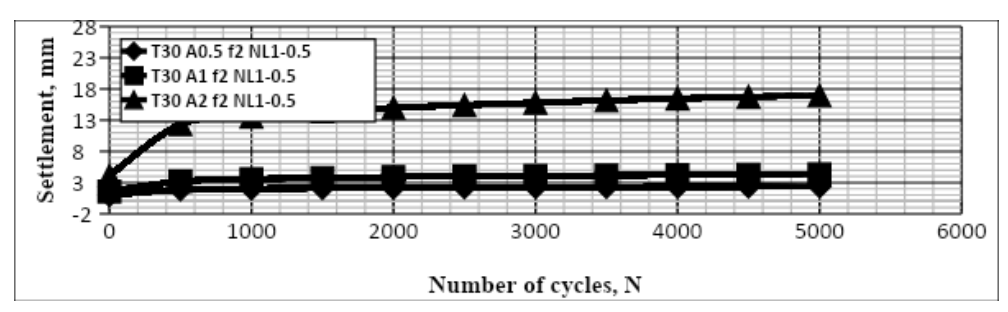

Figure 29. Settlement versus number of cycles for different load amplitudes with ballast thickness $30 \mathrm{~cm}$, frequency $2 \mathrm{~Hz}$ and with one layer reinforcement $\mathrm{h} / \mathrm{T}=0.5$.

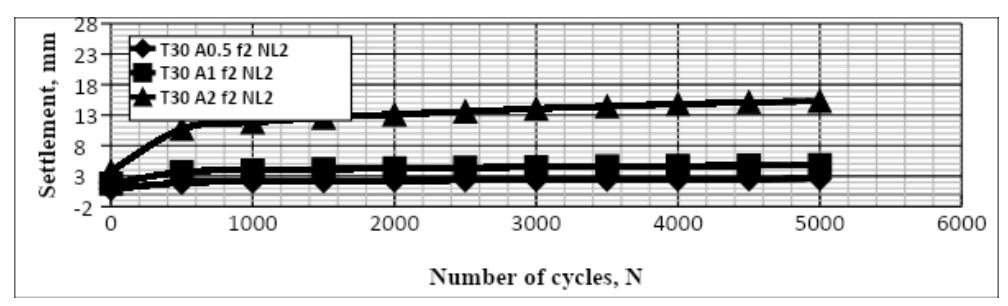

Figure 30. Settlement versus number of cycles for different load amplitudes with ballast thickness $30 \mathrm{~cm}$, frequency $2 \mathrm{~Hz}$ and with two layer reinforcement $\mathrm{h} / \mathrm{T}=0.25$.

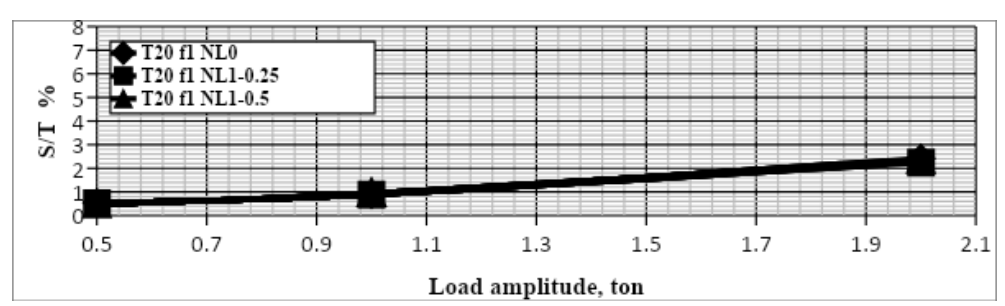

Figure 31. Effect of load amplitude on settlement ratio at the beginning of the test, with ballast thickness $20 \mathrm{~cm}$, frequency $1 \mathrm{~Hz}$. 


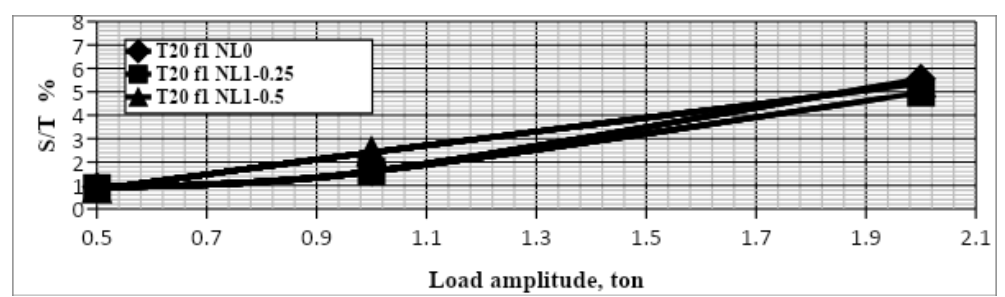

Figure 32. Effect of load amplitude on settlement ratio with ballast thickness $20 \mathrm{~cm}$, frequency $1 \mathrm{~Hz}$ after 500 cycles.

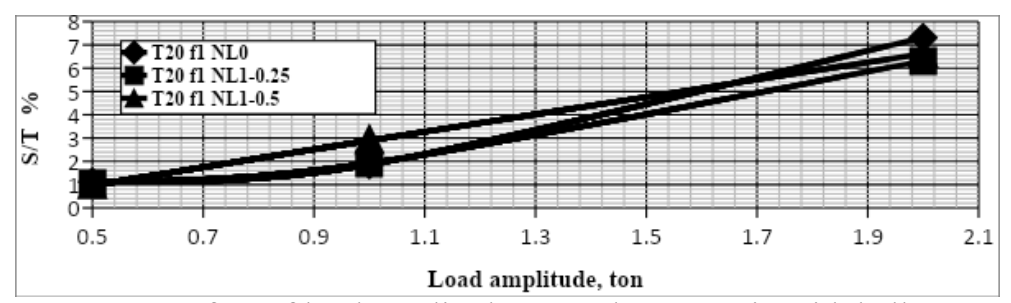

Figure 33. Effect of load amplitude on settlement ratio with ballast thickness $20 \mathrm{~cm}$, frequency $1 \mathrm{~Hz}$ after 2,500 cycles

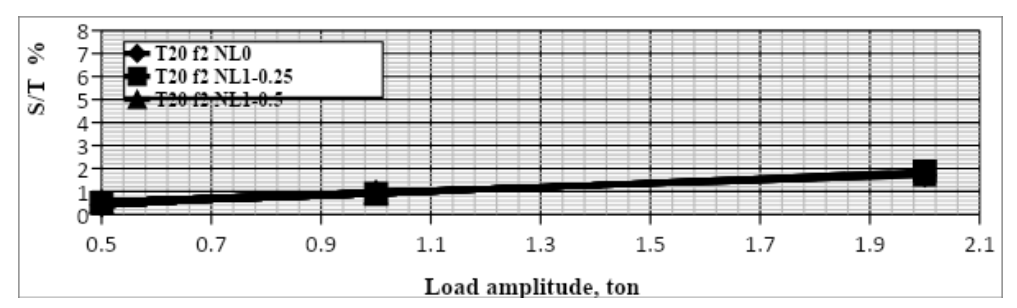

Figure 34. Effect of load amplitude on settlement ratio at the beginning of the test, with ballast thickness $20 \mathrm{~cm}$, frequency $2 \mathrm{~Hz}$.

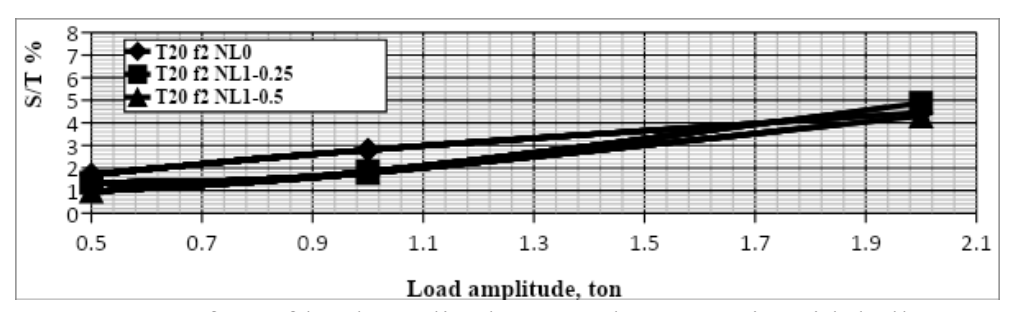

Figure 35. Effect of load amplitude on settlement ratio with ballast thickness $20 \mathrm{~cm}$, frequency $2 \mathrm{~Hz}$ after 500 cycles.

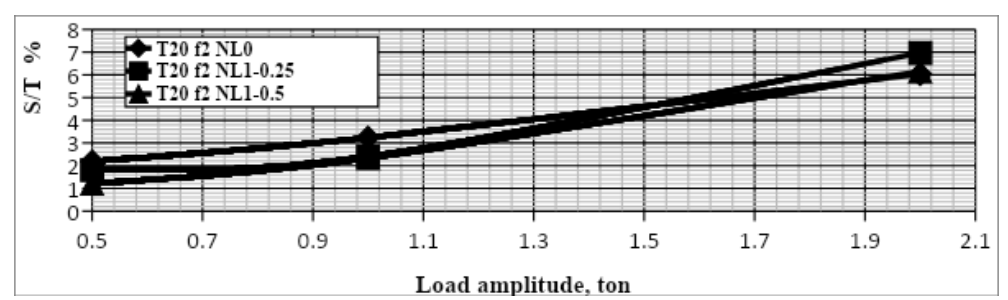

Figure 36. Effect of load amplitude on settlement ratio with ballast thickness $20 \mathrm{~cm}$, frequency $2 \mathrm{~Hz}$ after 4,500 cycles. 


\section{Conclusions}

The present work can be considered with the following limitations. The present work cannot be considered as a complete study of the response of reinforced ballast to dynamic loading which are restricted to the number of variables studied especially for the measurements of displacements and stresses inside soil media. Other parameters that influence the behavior of such a track system have not been taken into consideration in this work because of the limited time available and cost. Hence, the limitations within the testing program are:

The ballast railway reinforced by geogrid reinforcement is subjected to a dynamic load of half sine wave shape with a range of frequency between 1 and $2 \mathrm{~Hz}$ and load amplitude between 0.5 and 2 tons.

The experimental model is based on an approximate half-scale model for a general rail track engineering practice,

The soil used is soft to stiff clay, and

One type of geogrid reinforcement is used.

The following conclusions could be obtained:

The amount of settlement increased when the load amplitude increased, there was a sharp increase in settlement up to the 500 cycles and after that, there was a gradual increase, leveling out between 2,500 to 4,500 cycles, depending on the load frequency.

There was a little increase in the induced settlement when the load amplitude increased from 0.5 to 1 ton but it was higher when the load amplitude increased to 2 tons. The increasing amount in settlement depends on the presence of the geogrid and the other studied parameters.

For most cases and in all stages of the tests at low load amplitude ( 0.5 ton), there was almost equal settlement for reinforced and unreinforced ballast layers. The effect of load amplitude on the settlement of the composite was almost negligible in the beginning of the tests with reinforced and unreinforced ballast layers, so the settlement ratio (S/T) (the cumulative settlement (S) divided by ballast thickness (T)) difference was small between them while it increased with an increase in the number of cycles.

The effect of load amplitude on the settlement of the composite in the beginning of the tests was almost negligible with reinforced and unreinforced ballast layers, so the settlement ratio difference was small between them, while it increased with an increase in the number of cycles.

The initial settlement ratio for 2 tons amplitude varied between 1-2\% while for 0.5 and 1 ton amplitude, it varied between 0.5-1 percent.This observation includes reinforced and unreinforced ballast. 
There was little difference between the performance of placing the geogrid at the middle of the ballast layer or placing two geogrid layers than placing one geogrid layer in the bottom of the ballast layer. Almost the best geogrid position $\mathrm{h} / \mathrm{t}$ is 0.25 , i.e. when the ballast layer is lying on soft clay but it is not the case in stiff clay.

It is recommended to make laboratory tests on ballast material. More tests should be conducted on other types of fresh and recycled ballast to confirm the observations made for ballast used in this study. More test results can be generated with installation of different ballast materials. For example, each section can be filled with different sizes of ballast to observe the resulting breakage.

Peer-review: Externally peer-reviewed.

Conflict of Interest: The authors has no conflict of interest to declare.

Grant Support: The authors declared that this study has received no financial support.

Hakem Değerlendirmesi: Dış bağımsız.

Çıkar Çatışması: Yazarlar çıkar çatışması bildirmemiştir.

Finansal Destek: Yazarlar bu çalışma için finansal destek almadığını beyan etmiştir.

\section{References}

Abu-Farsakh M.Y., Chen Q., Yoon S., (2008), "Use of Reinforced Soil Foundation (RSF) to Support Shallow Foundation", Louisiana Department of Transportation and Development, Louisiana Transportation Research Center.

ASTM D 422-00: "Standard test method for particle size-analysis of soils", American Society for Testing and Materials.

ASTM D 4318-00, "Standard test methods for liquid limit, plastic limit, and plasticity index of soils", American Society for Testing and Materials.

ASTM D 854-00: "Standard test method for specific gravity of soil solids by pycnometer", American Society for Testing and Materials.

Awoleye, E. O. A. (1993). "Ballast type - Ballast Life Predictions". Derby, British Rail Research LR CES 122, October 1993.

Chan W.K. (1990), "Permanent Deformation Resistance of Granular Layers in Pavement”, Ph.D. Thesis, University of Nottingham, United Kingdom.

Chen Q., (2007), “An Experimental Study on Characteristics and Behavior of Reinforced Soil Foundation”, Ph.D. Thesis, Louisiana State University and Agricultural and Mechanical College, Department of Civil and Environmental Engineering.

Fattah M. Y., Al-Baghdadi W., Omar M. and Shanableh A., (2010), “Analysis of Strip Footing Resting on Reinforced Granular Trench by the Finite Element Method”, International Journal of Geotechnical Engineering, Vol. 01, 4, pp. 471-482.

Fattah, M. Y., Mahmood, M. R., Aswad, M. F., (2019), "Stress Distribution from Railway Track over Geogrid Reinforced Ballast underlain by Clay”, Earthquake Engineering and Engineering Vibration, Vol. 18, No. 1, pp. 77-93, Springer.

Fattah, M. Y., Mahmood, M. R., and Aswad, M. F., (2020), "Effect of Track Speed on the Behavior of Railway Track Ballast System underlain by Clay", IOP Conference Series Materials Science and Engineering 737:012094, Fourth International Conference on Buildings, Construction and Environmental Engineering - BCEE4, Istanbul - Turkey October 7 - 9, 2019, DOI: 10.1088/1757-899X/737/1/012094. 
Geeta B., Bhadoriya S. S. and Sleem A., (2013), "Model Studies on Footing Beam Resting on Geogrid Reinforced Soil Bed", International Conference on Recent Trends in Applied Sciences with Engineering Applications, Vol.3, No.6, pp. 1-6.

Haas R., Walls J. and Carroll R.G., (1988), "Geogrid Reinforcement of Granular Bases in Flexible Pavements”, Transport Research Record 1188.

Hayano K., Ishii K. and Muramoto K., (2013), "Effects of Ballast Thickness and Tie-tamper Repair on Settlement Characteristics of Railway Ballasted Tracks", The 18th International Conference on Soil Mechanics and Geotechnical Engineering, Paris, pp. 1275-1282.

Heidari M. and El Naggar M. H., (2010),’Using Reinforced Soil Systems in Hammer Foundations”, Proceedings of the Institution of Civil Engineers, Ground Improvement 163, GI2, pp. 121-132.

Milligan, G.W.E. and Love, J.P. (1984), "Model Testing of Geogrids under an Aggregate Layer on Soft Ground", Proceedings of Conference on Polymer Grid Reinforcement, Thomas Telford. London. UK, pp. $128-138$.

Paute J. L., Hornych P., and BenabenJ. P., (1996),’Repeated Load Triaxial Testing of Granular Materials in the French Network of Laboratories des Ponts et Chausse'es", Flexible Pavements, Proc., Eur. Symp. Euroflex 1993, A. G. Correia, ed., Balkema, Rotterdam, the Netherlands, pp. 53-64.

Raymond G.P., (2001), "Reinforced Ballast Behavior Subjected to Repeated Loading”, Geotextiles and Geomembranes 20, pp. 39-61. 